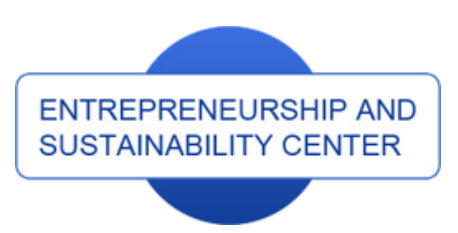

Publisher

http://jssidoi.org/esc/home

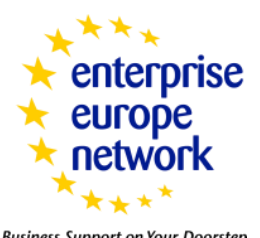

Business Support on Your Doorstep

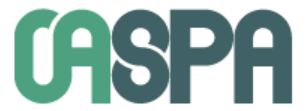

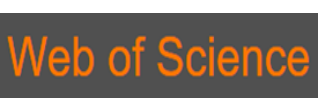

Clarivate
Analytics

\title{
VISUALIZATION OF EXPRESSING CULINARY EXPERIENCE IN SOCIAL NETWORK, MEMETIC APPROACH
}

\author{
Krzysztof Stepaniuk \\ ${ }^{B}$ ialystok University of Technology, Faculty of Management, Department of Tourist Economy \\ Tarasiuka 2 Street 16-001 Kleosin, Poland
}

E-mails: $\underline{\text { k.stepaniuk@pb.edu.pl }}$

Received 18 July 2017; accepted 10 December 2017; published 30 March 2018

\begin{abstract}
Objectives: The scientific aim of the study was the implementation of the assumptions of tourist experience formation model according to Quan and Wang (2004) in the context of meme theory (i.e. carriers of cultural information, Dawkins, 1976) for evaluation and visualization of the expression of regional cuisine culinary experience by social network users. The quality of culinary service influencing consumer's experience is equal to memetic transmission forming and broadcasting. Such type of transmission is acquired and decoded by consumers for further expression, i.a. through social networks. According to meme theory, the formation and expression of culinary experience is the building of memetic maps described by the frequency of the appearance of certain memes. Data and methods: Research included ten catering facilities, serving dishes of the regional cuisine (Polish, Belarussian, Ukrainian, Lithuanian and Tartar), located in the Podlaskie Voivodeship and having an active profile in Facebook social network. 370 comments were considered from the period between May and September 2016, referring to the contents connected only with the culinary offer of the facilities taken into account. The quantitative and qualitative content analysis was performed. The classification of emotion according to Xu et. al (2015) was used in the semantic decomposition of posted comments. Positive (enjoyment, confidence, safety, positive associations) and negative (dissatisfaction, distrust, anxiety, lack of positive associations) content of posted comments referred to the decor of the inside (mechanic factor), the quality of service (humanic factor) and served dishes (functional factor) were distinguished and analysed (Wall and Berry, 2007).Results: The analysis of the obtained meme maps suggests the presence of positive relationship between presence of memes of holistic enjoyment and enjoyment associated with regional dishes $\left(r_{s}=0.67 ; p<0,05\right)$. Similar relationship was observed between sense of enjoyment as well as the formation of positive associations with regional cuisine $\left(\mathrm{r}_{\mathrm{S}}=0.67 ; \mathrm{p}<0,05\right)$. Expression of anxiety is also highly connected with the negative perception of food quality $\left(\mathrm{r}_{\mathrm{s}}=0.65 ; \mathrm{p}<0,05\right)$. Conclusions: Meme theory is an effective and useful framework for social media content analysis. The study had utilitarian character. Results can be used for the establishment of a system of the recommendation towards improving the quality of regional cuisine culinary services.
\end{abstract}

Keywords: social network; user generated content; memes; meme transmission; culinary experience

Reference to this paper should be made as follows: Stepaniuk, K. 2018. Visualization of expressing culinary experience in social network, memetic approach, Entrepreneurship and Sustainability Issues 5(3): 693- 702. http://doi.org/10.9770/jesi.2018.5.3(21)

JEL Classifications: D09, Z19 


\section{The International Journal}

ENTREPRENEURSHIP AND SUSTAINABILITY ISSUES

ISSN 2345-0282 (online) http://jssidoi.org/jesi/

2018 Volume 5 Number 3 (March)

http://doi.org/10.9770/jesi.2018.5.3(21)

\section{Introduction}

The gastronomy and culinary base play an important role in creating the economic development of the destination (Hall, 2012; Jurigová et al., 2017). The Author argues that food consumption is integral to tourism and its economic impact can be important not only for immediate businesses that directly provide food for tourists (such as hotels, restaurants and attractions), it can also have significant economic impact throughout the food supply chain. The author claims that food tourism can be linked with other visitor products such as cultural and natural heritage attractions, thereby providing a comprehensive offer.

Regional cuisine is also the cultural expression of destination image. Baloglu i McCleary (1999), suggest that the cultural elements are next to nature and the overall experience, the fundamental factors shaping the image of the destination, it can be said that the local cuisine is one of the elements of destination expression, and thus is one of the most important distinguishing features of the image of a destination. These are also the elements that affect the emotions of the recipient.

A tourist trip is the sum of experiences, where the culinary experience is only one of the elements of a holistic tourism experience. Quan and Wang (2004) suggest that cooking - including local, site, region, or area-specific cuisines - are among the basic building blocks of experience related to a destination. Thus, they reflect on the satisfaction from the trip, directly influencing the "lasting memory about the experience." Thus an associative network is created between the meanings (knowledge), referring to the essence of the destiny (Conner et al., 2017, Erjavec et al., 2016). Berger et. al. (2004), using the approach of associative networks, define knowledge as "semantic relationships between domain-intrinsic information items". This approach is consistent with meme theory (Dawkins, 1976), i.e. replicators of cultural information. The scientific goal of the work was to implement the assumptions of the meme theory for the purpose of analysing the culinary experience externalized as the content of social networks. The utilitarian goal was to develop theoretical assumptions for the recommendation system, creating and presenting culinary products, i.e. creating descriptions and product images taking into account the perception of users.

\section{Literature overwiev}

Kaplan and Haenlein (2010) have defined social media (SM) as a tool usable for creation and sharing the User Generated Content (UGC). The typology of SM including: media sharing platforms, review sites, social networks, blogs, wikis (Gandomi, \& Haider, 2015, Potkány, \& Hajduková, 2015). All of these types of social media "rely on user-generated content provide their users tools to contribute data, whether through a profile, video, comment, or other means" (Silva and Panahi, 2017). UGC is perceived as content created and shared by social media users for other social media users. It is the richest source of information about experiences, behaviours, attitudes, lifestyles, opinions and feelings of their authors. Luca (2015) indicated the most popular types of UGC. It was as follows: pictures, personal updates and networking, reviews for products and services, encyclopaedia and reference sites, videos, payments, comments, etc. Such types could have different emotional character. In the case of posted comments, their semantic content could be perceived as positive, neutral or negative sets of emotions (Xu et al. 2015). Simultaneously such positive, neutral or negative expression of attitudes could be referred entirely or partly to phenomena, product or service. Wall et al. (2007) in the case of culinary service suggest that, ,diners use the following types of clues to judge a restaurant experience: functional - the technical quality of the food and service; mechanic - the ambience and other design and technical elements; and humane-the performance, behaviour, and appearance of the employees." Such approach is common with systemic perception of service quality and taken into account (Urban, 2007 based on: Lehtinen and Lehtinen, 1991 and Johnson et al. 1995):

- quality of input: among others attributes concerning service personnel, interior and equipment;

- quality of process: among others, courtesy and friendliness of the staff, quality and aesthetics of the food served; 
- quality of output: contains mental changes resulting from the use of the service.

The formation of changes in the mental state of the recipient justifies the memetic approach.

Memes are the replicators of cultural information (Dawkins, 1976). According to Shifman (2013), memes have a few basic attributes:

Content - part of the text, an image or a fragment, or any other form of a communication and the meaning, which it - (information transmission);

Form - nature of visualization / manifestation of a communication in the form of text, images, melodies;

Stance - concerns the relationship between the sender and the message content as well as the form and its recipient, the relation between the addresser, the information content and form, and of course the addressees.

Memes, analogous to genes, compete with each other for existence in the population. The memes having the greatest chance for dissemination and survival are the ones characterized by, inter alia, efficient duplication, faithfulness of message, copy durability (Boski, 2010). It is possible to visualize the incidence of memes by creating meme maps. A meme map is also a visualization of the mental construct, which expresses the way of perceiving a particular phenomenon (Atadli et al. 2017). Henderson (1998) suggests that simultaneously it is the expression of individual pattern of individual's reality perception manner. It was referred to all aspects of human activity, including product experience. Hekkert \& Schifferstein (2008) defined the product experience as 'the awareness of the psychological effects elicited by the interaction with a product, including the degree to which all our senses are stimulated, the meanings and values we attach to the product, and the feelings and emotions that are elicited'. According to Quan and Wang (2004), tourist experience is influencing by tourist expectations and product performances and tourist satisfaction. The quality of food is decisive for tourist satisfaction as well as for holistic tourist experience, when food produces "lasting memory of experience".

\section{Materials and methods}

The work was carried out using quantitative and qualitative analysis methods. It has been assumed that the comments left on the regional profiles of the restaurants are a direct expression of the culinary experience. It may have a negative or a positive impact. This experience is also of a memetic nature. Memes are created (are received) at the stage of service consumption, cause mental changes in the recipients, and can be transferred and / or expressed. The expressions of mental changes are included in the comments in the form of various emotional meanings (memes) relating to a specific aspect of the service, i.e.: functional, mechanic and humanic elements of culinary experience" (Wall et al. 2007). These memes occur with different frequencies, thus creating a meme subpool relating to the manner of perception and expression of culinary experience. The semantic decomposition of comments allows to isolate the individual elements of experience and to visualize them. At the same time, it is possible to indicate the source of the factor to which the relevant element of experience relates (functional, mechanical and human factors of culinary experience).

The object of the study were comments left by the users of the Facebook social network, and left on the official profiles of the restaurant in the region of Podlasie, offering regional cuisine. The modified methodology according to (Marine-Roig and Clavé, 2015) was applied, which including:

1. Facebook profiles selection (analysed profiles, founded using Facebook search engine with using keywords: regionalna kuchania podlaska (regional podlaskie cuisine) referred only to restaurants; the profile were selected when possess more than 30 posted comments related to the culinary experience);

2. data collection (founded comments were downloaded and archived);

3. data pre-processing (including content mining which extracting based information about authors of each comment); 4. content analysis (semantic decomposition of each comment according to criteria shown on Fig. 1). 370 comments were taken into account, 500 posts were gathered in the course of the study, shared by the administrators of the profiles and relating directly to the culinary service alone. The comments not related to cuisine were omitted. The details are presented in Table 1. 
Table 1. Object of the study

\begin{tabular}{|l|l|l|l|}
\hline $\begin{array}{l}\text { Name of the } \\
\text { establishment }\end{array}$ & Profile address & $\begin{array}{l}\text { Number of posts } \\
\text { analysed }\end{array}$ & $\begin{array}{l}\text { Number of comments } \\
\text { included }\end{array}$ \\
\hline Babka Białystok & www.facebook.com/Babka.Bialystok & 50 & 50 \\
\hline $\begin{array}{l}\text { Restauracja Stoczek } \\
\text { Białowieża }\end{array}$ & www.facebook.com/Stoczek1929 & 50 & 50 \\
\hline $\begin{array}{l}\text { Abro Kuchnia i Bar } \\
\text { Suwałki }\end{array}$ & $\underline{\text { www.facebook.com/abrobar }}$ & 50 & 30 \\
\hline $\begin{array}{l}\text { Folwark Nadawki } \\
\text { Karczma Polska } \\
\text { Suwałki }\end{array}$ & $\underline{\text { www.facebook.com/Folwark-Nadawki- }}$ & 50 & 30 \\
\hline $\begin{array}{l}\text { Tatarska } \\
\text { Kruszyniany }\end{array}$ & $\begin{array}{l}\text { www.facebook.com/Tatarska-Jurta- } \\
\text { 589059724453980 }\end{array}$ & 40 \\
\hline $\begin{array}{l}\text { Galeria Sztuki i Smaku } \\
\text { "Opowieści z Narwi" }\end{array}$ & $\begin{array}{l}\text { www.facebook.com/Galeria-Sztuki-i-Smaku- } \\
\text { Opowieści-z-Narwi--671574376265133 }\end{array}$ & 50 & 40 \\
\hline Restauracja "U Ireny" & $\begin{array}{l}\text { www.facebook.com/Restauracja-noclegi-U- } \\
\text { Ireny-w-Drohiczynie-174873735905837 }\end{array}$ & 50 & 30 \\
\hline $\begin{array}{l}\text { Wiszące Ogrody nad } \\
\text { Narwią }\end{array}$ & $\underline{\text { www.facebook.com/wiszaceogrodynadnarwia }}$ & 50 & 30 \\
\hline Karczma Litewska (lit) & $\underline{\text { www.facebook.com/karczma.litewska }}$ & 50 & 40 \\
\hline
\end{tabular}

Source: own elaboration

Preliminary semantic analysis of the collected research material revealed the existence of four main types of positive emotion memes, and their opposites. These were: satisfaction or lack thereof, a sense of security or lack thereof, confidence or lack thereof, and the creation of positive associations or lack thereof, referring to functional, mechanic and human factors of culinary service (Fig. 1).

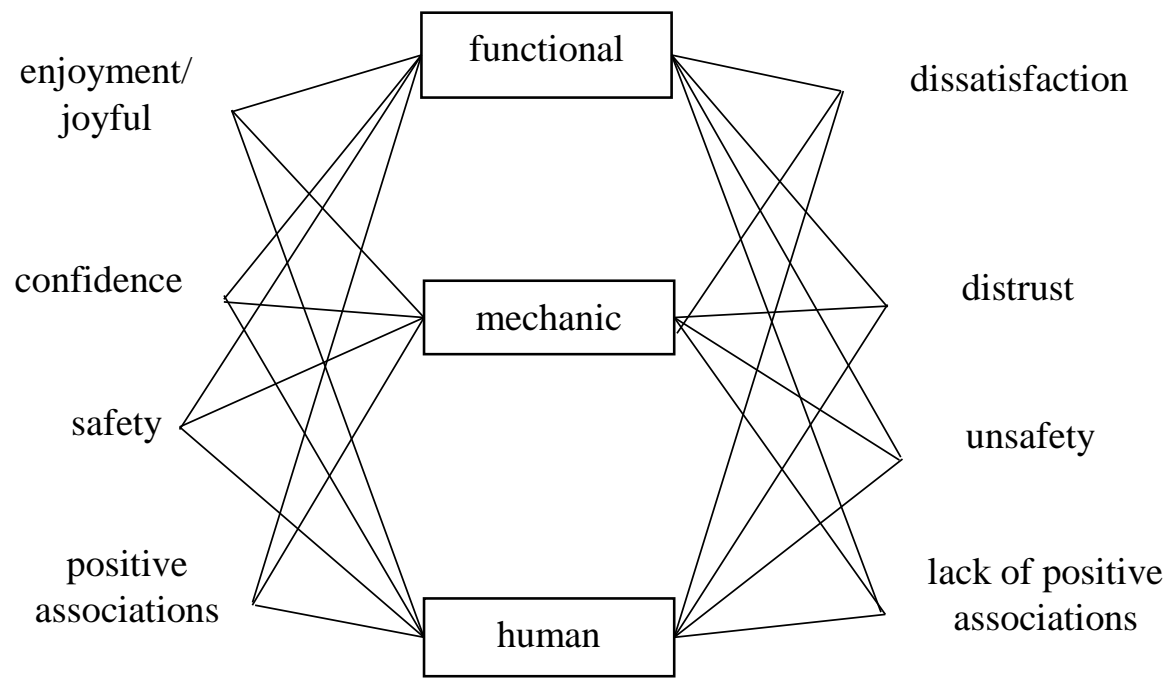

Fig. 1. Theoretical framework of the study Source: own elaboration 
With this in mind, the following sub-hypotheses were formulated:

H1: The memetic pool expressing culinary experience will most likely be dominated by the memes connected with the emotions referring to the functional factor of culinary experience, although mechanic and human factors do not have important influence on the formation and transfer of emotion memes.

H2: The analysis of meme maps, which are the expression of the memetic pool, enables the study of the way of perception and expression of culinary experiences and could be useful in management of quality of regional culinary services.

Descriptive statistics were used to present the results. The Spearmann correlation coefficient was used to analyse the relationship between the individual emotion memes and the components of the culinary experience. Statistical analysis was performed with the use of STATISTICA 12.

\section{Results}

The research analysed the contents of 370 comments, 198 of which were authored by women and 172 by men. Each entry was characterized by the presence of positive and / or negative emotion memes. Positive connotations in relation to culinary experience were expressed mainly in relation to dish quality (functional factor) and service quality (human factor). The elements that determine the formation of sensations associated with the specificity of an interior (mechanic factor) were expressed the least often. The externalization and further dissemination of negative emotions remained roughly at the same level with respect to each of the elements of culinary experience. For more details see on Fig. 2.

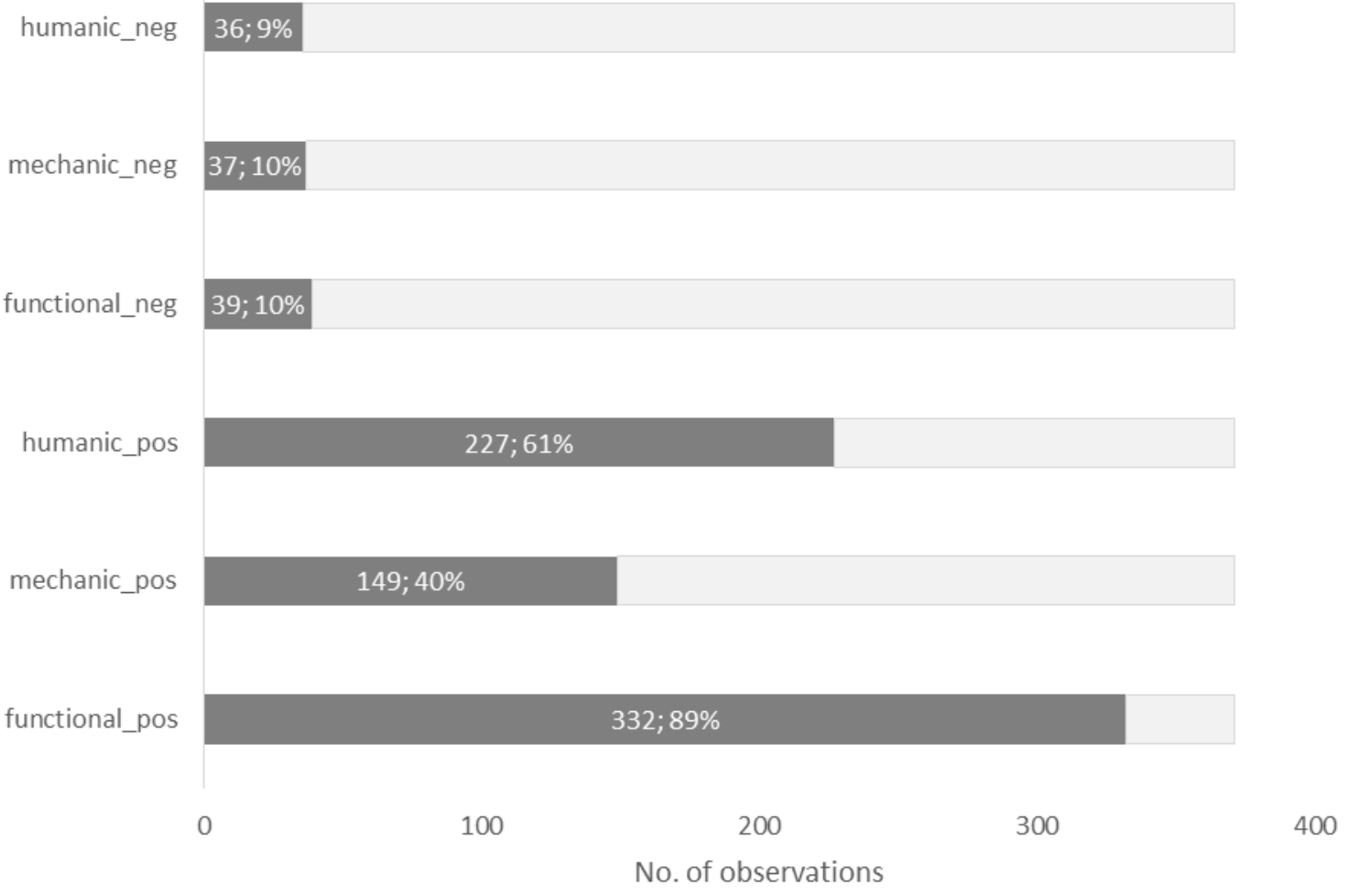

Fig. 2. The frequency of occurrence of positive and negative associations with regional culinary experience, based on semantic analysis of posted comments on regional cuisine entities from podlaskie region $(n=370)$

Source: Own elaboration 
The most frequently, from the perspective of the total amount of analysed comments, the most commonly encountered were the expressions of satisfaction (91.9\%) and positive associations with the service, for example, referring to e.g. the family home (92\%). These memes are very strongly correlated with each other $(\mathrm{rS}=0.98, \mathrm{p}$ $<0.05)$. The expression of confidence in the service and the sense of security occurred with a frequency of $73 \%$ and 54\%. Memes related to satisfaction are also positively correlated with the expression of confidence $(\mathrm{R}=046$, $\mathrm{p}<0.05)$ and the sense of security $\left(\mathrm{r}_{\mathrm{S}}=0,98, \mathrm{p}<0,05\right)$.

Memes with negative emotional overtones appeared with a far lower frequency. Disappointment, lack of sense of security and lack of positive associations appeared in $8 \%$ of comments. Lack of confidence occurred in $11 \%$ of opinions. More details are shown on fig. 2.

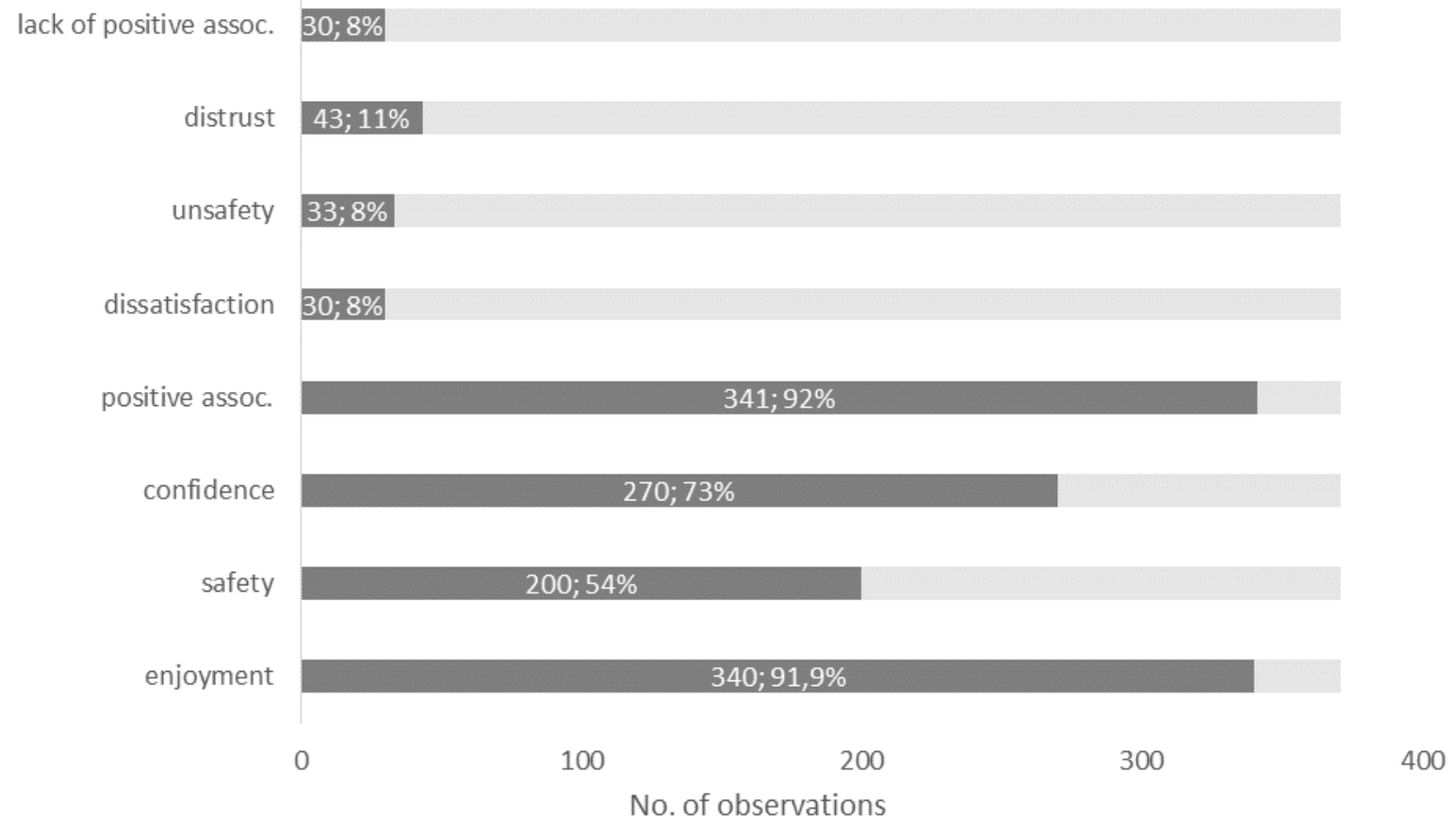

Fig. 2. Memetic map based on the frequency of occurrence of positive and negative memes of emotions on analysed comments ( $\mathrm{n}=370)$ Source: Own elaborations

The analysis of Spearmann correlation coefficient values indicates a significant relationship between the quality of the served dishes (functional factor of experience) and the emergence and further extension of satisfaction. A similar association was also found in the case of the meme of association of the current situation with previous memories (i.e. generation of positive associations) as well as the meme of trust. The interior design (mechanic factor) has little or no influence on the creation of positive emotions memes. Quality of service (human factor) has little significance in the case of memes of satisfaction, confidence, and positive associations. But it does not affect the formation of the meme of the sense of security. More details are shown on Table 2. 
Table 2. Spearmann correlations between memes of positive emotions and elements of culinary experience $(\mathrm{p}<0,05)$; where: $<0.2-$ lack of relation; 0.2 - 0.4 - minor relation; $0.4-0.7$ - moderate relation; 0.7 - 0.9 - quite strong relation; $>0.9$ - very strong relation

\begin{tabular}{|c|c|c|c|}
\hline \multirow[b]{2}{*}{ Memes of: } & \multicolumn{3}{|c|}{ Components of culinary experience } \\
\hline & humanic & functional & mechanic \\
\hline Enjoyment & 0,333586 & 0,649691 & 0,203526 \\
\hline safety & 0,192646 & 0,277631 & 0,159891 \\
\hline Confidence & 0,266848 & 0,415578 & 0,201895 \\
\hline Positive associations & 0,326121 & 0,663230 & 0,198444 \\
\hline
\end{tabular}

Source: own elaboration, with using STATISTICA 12

Functional factor of culinary experience as well as human factor has the biggest effect on creation and dissemination of memes of dissatisfaction, unsafety, distrust and lack of positive associations. There is small effect or lack of dependence between thee memes and mechanic factor (Table 3).

Table 3. Spearmann correlation between memes of negative emotions and the elements of culinary experience ( $\mathrm{p}<0,05)$; where: $<0.2$ lack of relation; 0.2 - 0.4- minor relation; $0.4-0.7$ - moderate relation; $0.7-0.9$ - quite strong relation; > 0.9 - very strong relation

\begin{tabular}{|l|l|l|l|}
\hline \multirow{2}{*}{ Memes of: } & \multicolumn{2}{|l|}{ lomponents of culinary experience } \\
\cline { 3 - 4 } & humanic & functional & mechanic \\
\hline dissatisfaction & 0,470450 & 0,671905 & 0,147220 \\
\hline unsafety & 0,537199 & 0,664597 & 0,205724 \\
\hline distrust & 0,592340 & 0,699415 & 0,223965 \\
\hline Lack of positive associations & 0,470450 & 0,671905 & 0,147220 \\
\hline
\end{tabular}

Source: own elaboration

\section{Discussion}

The results of the study indicate that the hypothesis concerning the dominant role of the functional factor in the culinary experience formation is appropriate. The memes of satisfaction and positive associations are dominant in the constructed memetic map and constitute a substantial correlation in the functional factor. Therefore, the results of the research also indicate that the creation and expression of a particular emotion meme is correlated with the elements of culinary experience. Most often it relates to the functional and human factors. Such type of dependence is minor in the case of the mechanic factor. These results may confirm the research conducted by Mkono et al. (2013), who indicated that the culinary experience related to untypical flavours and culinary compositions is an element that builds tourist satisfaction and significantly influences the holistic tourist experience. From the perspective of creating positive associations between local cuisine and a location, it can be seen as a peak of such experience. Hence, building a memetic map relating to an experience can help in determining the key elements of the culinary service for a particular destination. This, in turn, translates into building mental, positive associations connected with a destination, and thus creating the attitudes of loyalty in the consumers. However, in the case of certain products, e.g. vine, sushi, Taar (2017) notes an interesting correlation associated with assigning them the culinary role, causing direct consumer satisfaction, regardless of the taste values, etc. These may be culinary items which, in certain social groups, are perceived as exemplary and, perhaps, elevating the prestige of the consumer. 


\section{The International Journal}

ENTREPRENEURSHIP AND SUSTAINABILITY ISSUES

ISSN 2345-0282 (online) http://jssidoi.org/jesi/

2018 Volume 5 Number 3 (March)

http://doi.org/10.9770/jesi.2018.5.3(21)

Interesting work in the field of mapping culinary experience was realized by Byrnes et al (2015). Analyzing the manner of perceiving odor stimuli (chemesthetic stimuli) by experts and people with no culinary practice/experience, they have demonstrated that the manner of expressing certain odor stimuli varied in the case of different groups. Therefore, as stated by Giboreau (2017) "context needs to be studied more by adding variables to current research protocols and the foodservice practices are helpful to structure and choose the relevant variables for each project."

Referring to the results of the presented research, it is important to emphasize the important role of analysing socio-economic variables in the study of perception of culinary experience. Unfortunately, in the case of netnographic methodology (Jemielniak, 2013) and the specifics of the data contained in social networks, this can be embarrassing and sometimes unfeasible.

\section{Conclusions}

The subject of the work was the formation and transfer of memes relating to emotions. Hekkert and Schifferstein, 2008 suggest the important role of the emotional factor in the perception of the product and the way it is experienced. Similarly, according to Schifferstein (2010), each of the human senses is sensitive to the different types of stimulation, and experiencing products and services in a holistic manner is associated with ,incoming sensory information". Such type of transmission It can have various effects on the functioning of humans, i.e. their affective, cognitive and behavioural activities. In addition, the influx of information ,may evoke memories or associations". The formation of memories or relationships is a mental change being a derivative of consummating, decoding and assimilating a particular meaning. In turn, this meaning can be transferred and, depending on the social environment (virtual and real), spread in different ways. In the analysed case, the content diffusion environment was a social network. Memetic content has been included in selected UGC (textual) resources. The semantic decomposition of the collected comments allowed to isolate memes of emotions and create a map showing the frequency of their occurrences. Because of its properties, the UGC is also an element that allowing for a further transfer of generated emotions. The representation of such a transfer is the creation of a memetic map showing the participation of particular groups of emotion memes in the general way of perceiving certain phenomena (in this case regional culinary experience). The resulting map is, in a sense, a quasi-ontological image of part of the culinary experience along with its associations. In this map, from the perspective of the formation of perception of the tourist experience, the key role is played by the functional and human factor of culinary experience. The element specific to the destination (e.g. related to cultural characteristics), the mechanic factor, does not usually play a key role, is least represented. and does not show significant correlation with emotion memes. Similar considerations related to the general memes are presented, among others, by Atadil et al. (2017). The authors, based on the results of the analysis of meme maps for Antalya, based on the qualitative attributes of this destination, suggest that the so called general memes are key elements for creating memories and declaring another visit. However, it is equally important to create, as in the case under analysis, with a significantly lower frequency, and the externalization of unique memes. The authors cited above indicate the differences in the composition and the frequency of occurrence of memes unique in the memories of various visitors of different nationalities.

Building memetic maps through semantic decomposition and UGC analysis can be an important contribution to building a marketing message targeted at different segments of the market. It also could be used in management and improvement of quality of regional culinary services. It may also be a contribution to a careful analysis of the perception of reality typical of a location through the use of diverse market segments. The conducted research, due to its pilot nature, only referred to testing the possible methodology of decomposition and basic analyses related to the constructed memetic map. Further work should be concerned with defining the way in which 


\section{The International Journal}

ENTREPRENEURSHIP AND SUSTAINABILITY ISSUES

ISSN 2345-0282 (online) http://jssidoi.org/jesi/

2018 Volume 5 Number 3 (March)

http://doi.org/10.9770/jesi.2018.5.3(21)

emotional memes are exposed to the behavioural aspects of functioning of social networking users who consume shared content. This concerns above all the relationship between the number and nature of emotional memes and the organic range of the element in which they are contained.

\section{References}

Atadil HA, Sirakaya-Turk E, Baloglu S and Kirillova K. (2017) Destination Neurogenetics: Creation of destinationmememaps of tourists, Journal of Business Research Volume 74: 154-161. http://dx.doi.org/10.1016/j.jbusres.2016.10.028

Baloglu S and McCleary KW. (1999) A model of destination image formation. Annals of Tourism Research 26(4): 868-897. http://dx.doi.org/10.1016/S0160-7383(99)00030-4

Berger H, Dittenbach M. and Merkl D. (2004) An accommodation recommender system based on associative networks.

https://www.cabdirect.org/cabdirect/abstract/20043052810

Boski P. (2010) Kulturowe ramy zachowań społecznych. Podręcznik psychologii międzykulturowej (Cultural Frames of Social Behaviours. Intercultural Psychology Handbook), Wydawnictwo Naukowe PWN, Warszawa: 24-25

Byrnes NK, Loss ChR and Hayes JE. (2015) Perception of chemesthetic stimuli in gropus who differ by food involvement and culinary experince, Food Quality and Preference, Volume 46: 142-150. http://dx.doi.org/10.1016/j.foodqual.2015.07.017

Cairo, Egypt: Springer. International Journal of Information Management Volume 35: 137-144. http://dx.doi.org/10.1016/j.ijinfomgt.2014.10.007

Conner SL, Reardon J, Miller C, Salciuviene L and Auruskeviciene V. (2017) Cultural antecedents to the normative, affective, and cognitive effects of domestic versus foreign purchase behavior, Journal of Business Economics and Management 18(1): 100-115. https://doi.org/10.3846/16111699.2016.1220975

Dawkins R. (1976). The selfish gene. Oxford, England: Oxford University Press effects using consumer associative networks. European Journal of Operational

Erjavec HŠ, Dmitrović T and Bržan PP. (2016) Drivers of customer satisfaction and loyalty in service industries, Journal of Business Economics and Management 17(5): 810-823. https://doi.org/10.3846/16111699.2013.860614

Gandomi A and Haider M. (2015) Beyond the hype: Big data concepts, methods, and analytics https://doi.org/10.1016/j.ijinfomgt.2014.10.007

Cairo, Egypt: Springer. International Journal of Information Management Volume 35: 137-144. $\underline{\text { http://dx.doi.org/10.1016/j.ijinfomgt.2014.10.007 }}$ Giboreau A. (2017) Sensory and consumer research in culinary approaches to food, Current Opinion in Food Science (In Press, available Online). http://dx.doi.org/10.1016/j.cofs.2017.06.001

Hall CM. (2012) Boosting food and tourism-related regional economic development. In: OECD, Food and the Tourism Experience: The OECD-Korea Workshop, OECD Studies on Tourism, OECD Publishing: 49-62.

Hekkert P and Schifferstein HNJ. (2008) Introducing product experience. In H. N. J. Schifferstein \& P. Hekkert (Eds.), Product experience (pp. 1-8). Amsterdam: Elsevier.

Henderson GR, Iacobucci D and Calder BJ. (1998). Brand diagnostics: Mapping branding system based on associative networks. Proceedings of the 11th International Conference

Johnson RL, Tsiros M and Lancioni RA. (1995) Measuring service quality: a systems approach. Journal of Services Marketing Volume 9(5):6-19. http://dx.doi.org/10.1108/08876049510100272

Jurigová Z., Tučková Z., Solenes O. (2017). The impact of chosen economic indicators on tourism sustainability: case study of the Czech Republic and Norway. Journal of Security and Sustainability Issues 7(1): 113-121. https://doi.org/10.9770/jssi.2017.7.1(9)

Kaplan A and Haenlein M. (2010) Users of the world, unite! The challenges and opportunities of social media, Business Horizons Volume 53(1): 59-68. https://doi.org/10.1016/j.bushor.2009.09.003

Lehtinen UL and Lehtinen JR. (1991) Two Approaches to Service Quality Dimensions. Service Industries Journal: 113:287-303. http://dx.doi.org/10.1080/02642069100000047

Luca M. (2015) User-Generated Content and Social Media, Handbook of Media Economics, Volume 1: 563-592. http://dx.doi.org/10.1016/B978-0-444-63685-0.00012-7

Marine-Roig E and Clavé SA. (2015) Tourism analytics with massive user-generated content: A case study of Barcelona, Journal of Destination Marketing \& Management, 4(3): 162-172. http://dx.doi.org/10.1016/j.jdmm.2015.06.004

Mkono M, Markwell K and Wilson E. (2013) Applying Quan and Wang's structural model of the tourist experience: A Zimbabwean netnography of food tourism, Tourism Management Perspectives, Volume 5: 68-74. http://dx.doi.org/10.1016/j.tmp.2012.10.007.

on Information and Communication Technologies in Tourism (ENTER 2004).

Potkány, M. and Hajduková, A. (2015). Social Networks and their Importance in Job Searching of College Students, Business: Theory and Practice, Business: Theory and Practice 16: 75-83. https://doi.org/10.3846/btp.2015.462

Quan S and Wang N. (2004) Towards a structural model of the tourist experience: an illustration from food experiences in tourism, Tourism Management, Volume 25(3): 297-305. http://dx.doi.org/10.1016/S0261-5177(03)00130-4 
The International Journal

ENTREPRENEURSHIP AND SUSTAINABILITY ISSUES

ISSN 2345-0282 (online) http://jssidoi.org/jesi/

2018 Volume 5 Number 3 (March)

http://doi.org/10.9770/jesi.2018.5.3(21)

Schifferstein HNJ. (2010) From salad to bowl: The role of sensory analysis in product experience research, Food Quality and Preference Volume 21(8): 1059-1067. http://dx.doi.org/10.1016/j.foodqual.2010.07.007

Silva L and Panahi H. (2017) Catch me if you can: Online protests on sites powered by user-generated content, Information \& Management, Volume 54(1): 103-114,. https://doi.org/10.1016/j.im.2016.04.006

Taar J. (2014) The Best Culinary Experience. Factors that Create Extraordinary Eating Episodes, Procedia - Social and Behavioral Sciences, Volume 122: 145-151. http://dx.doi.org/10.1016/j.sbspro.2014.01.1317

Urban W. (2007) Definicje jakości usług - różnice oraz ich przyczyny [Definitions of service quality - differences and their reasons]. Problemy Jakości Volume 3: 4-9.

Wall EA and Berry LL. (2007) The Combined Effects of the Physical Environment and Employee Behavior on Customer Perception of Restaurant Service Quality Cornell Hospitality Quarterly Volume 48(1): 59 - 69. http://ds.doi.org/10.1177/0010880406297246

$\mathrm{Xu} \mathrm{H}$, Yang W and Wang J. (2015) Hierarchical emotion classification and emotion component analysis on Chinese micro-blog posts, Expert Systems with Applications, Volume 42(22): 8745-8752. http://dx.doi.org/10.1016/j.eswa.2015.07.028

\section{Krzysztof STEPANIUK}

ORCID ID: $\underline{\text { http://orcid.org/0000-0003-4071-1053 }}$

Copyright (C) 2018 by author(s) and VsI Entrepreneurship and Sustainability Center

This work is licensed under the Creative Commons Attribution International License (CC BY).

http://creativecommons.org/licenses/by/4.0/

c) (7) Open Access 